\title{
ANALYSIS OF THE BENEFITS OF CORPORATE SOCIAL RESPONSIBILITY THROUGH THE TRIPLE BOTTOM LINE APPROACH AT PT. TIRTA INVESTAMA INDONESIA
}

\author{
Samsudin Acep*, Raharja Sam’un Jaja, Saefullah Djadja, Rizal Muhamad \\ Business Administration, University of Padjadjaran, Indonesia \\ *E-mail: acepsamsudinummi@gmail.com
}

\begin{abstract}
The role of Corporate Social Responsibility (CSR) has become increasingly important in the current era of globalization. This was triggered by the ecosystem of company activities to create business operational sustainability amid the local community environment. The implementation of CSR must emphasize economic, social and environmental aspects based on three basic principles which include profit, people and the planet (triple bottom line). This study aims to determine the extent to which the benefits of CSR carried out by PT. Tirta Investama. This research shows whether the company does not only focus on the interests to gain profit, but also focuses on the interests of the company's external environment. The research method used is a descriptive qualitative approach through deep interview to informants related to the research question in this study. The results of the study show that PT. Tirta Investama cannot ignore the role of the company's external environment, such as social, economic and environmental conditions of the local community. Concern for the community will have a big impact on increasing company profits and will create a sustainable competitive advantage. The conclusion in this study can be stated that PT. Tirta Investama has carried out CSR activities based on the triple bottom line, but the benefits received by the community have not been maximized and have not contributed significantly to improvements in the social, economic and environmental aspects of the local community.
\end{abstract}

\section{KEY WORDS}

Corporate social responsibility, triple bottom line, profit, people, planet.

The concept of Corporate Social Responsibility (CSR) has come to the attention of various parties and is often associated with sustainable development efforts (Bocken, Short, Rana, \& Evans, 2014; Tate, Ellram, \& Kirchoff, 2010). CSR affects the interests of social, economic and environmental, so that its application there is elements of externalities that not everything can be controlled company. Optimal CSR implementation requires directed and measurable synergy in order to obtain maximum final benefits. According to Elkington (1998) CSR is a business commitment to act ethically, operate legally and contribute to improving the quality of life of employees and their families, local communities, and the wider community. The concept of CSR involves the responsibility of partnerships between government, companies, and local communities that are active and dynamic (Bocken et al., 2014; Carter \& Easton, 2011).

CSR contains positive values on a voluntary basis that are formed humanistly (Hambrick, 1981; Sherman, 2012). Viewed from the standpoint of giving benefits to the companies, CSR is a form of persuasive profitable investment for the future. Forms of CSR activities are not tied to certain criteria. CSR fund distribution is generally carried out at the Company is domiciled (Davis, 2005; Freeman \& Hasnaoui 2011; Hidayati, 2011). Although there are no formal rules, the environment around the company is considered the most appropriate to receive CSR benefits given the high level of interaction and the most vulnerable to receiving negative impacts (Detre \& Gunderson, 2011) for the existence of the company (Bocken et al., 2014; Detre \& Gunderson , 2011).

Implementation of CSR in Indonesia based on the new legislation began in early 2000. PT. Tirta Investama (Aqua Group) has been implementing CSR since the establishment of the company but after legislation regulating Corporate Social Responsibility (CSR) in 2010, 
PT. Tirta Investama Cianjur Factory is increasingly active in implementing CSR programs. There are two things behind PT. Tirta Investama implements CSR, including external and internal factors. External factors, namely to get a positive image, good name, and get a place in the heart of the society. This is done so that people know the products from PT. Tirta Investama, which $\quad h$ is bottled drinking water with the name Aqua trade products, which ultimately sells the product in the market and to prevent the occurrence of social conflicts that most can disrupt the operational activities of PT. Tirta Investama in the Cianjur Factory area.

Judging from the empirical phenomenon, the benefits of CSR are still not really felt by the people around the Industrial Estate of PT. Tirta Investama. It is caused by various factors, such as non-optimal application of CSR has been done. Forms of activities that have been carried out by PT. Tirta Investama includes; (1) Community empowerment; (2) Economic improvement; (3) Company Social Relations; (4) Good Business Governance; (5) Maintaining Environmental Sustainability.

CSR activities at PT. Tirta Investama refers to three basic principles which include profit, people and planet (Tate et al., 2010) or called the triple bottom line approach (Elkington, 1998), meaning that companies do not only have economic and legal obligations to shareholders, but also obligations to stakeholders. Because companies cannot live, operate, and get profits without the help of other parties. CSR is a corporate decision making linked to ethical values (Freeman \& Hasnaoui 2011; Hidayati, 2011; Valor, 2005), in compliance with the rules and decisions of law and uphold the dignity of man, society and the environment (Bocken et al. , 2014; Freeman \& Hasnaoui, 2011). However, the final results felt by the society have not been thoroughly beneficial. The initial assumption that researchers can be regarded as an effort that is not optimal CSR activities conducted by PT. Tirta Investama.

Based on the explanation and empirical gap above, this article seeks to analyze the benefits of CSR through a triple bottom line approach at PT. Tirta Investama. Research with research focus of CSR have been carried out, (Bocken et al., 2014; Carter \& Easton, 2011; Sherman, 2012) and even the analysis of CSR through approach to the triple bottom line has also been widely studied (Detre \& Gunderson, 2011; Elkington, 2004; Norman \& MacDonald, 2012; Painter-Morland, 2006; Responsibility \& Dixon, 2014; ,ak, 2015), but the research question that arises is whether the implementation of CSR through a triple bottom line approach is carried out by PT. Tirta Investama has been optimal so as to produce great benefits for stakeholders and companies. On the other hand, the problems on the principle of the planet, or the external environment, play an important role in the continued operation of the company in the manufacture of bottled water by PT. Tirta Investama.

Problems that occur when the PT. Tirta Investama ignores the benefits of CSR, is the emergence of threats from various parties such as from the local community, environmental damage that impacts on natural resources as a provider of raw materials (Guillén \& Mele, 2006), as well as the company's external social environmental imbalances (Buhmann, 2006). Based on this background, then this article seeks to identify and analyze the extent to which the benefits of CSR PT. Tirta Investama through a triple bottom line approach.

\section{LITERATURE REVIEW}

The concept of CSR has evolved over time (Kleine \& von Hauff, 2009). In the past CSR was assumed to be a cost that was entirely non-cost recovery (Lu, Chau, Wang, \& Pan, 2014; Luu, 2017). Its presence is only a burden because the company seems to be forced to allocate a number of funds that have nothing to do with operational activities. But gradually this paradigm began to shift in line with the strengthening of the concept of value creation in corporate environments (Elkington, 1998).

CSR is a company's concern the activities of the external environment or stakeholders that is based on three basic principles (triple bottom line), with the 3P concept, namely: Profit, People and Planet. The triple bottom line concept was popularized by Elkington (1997) through his book Cannibals with forks, the Triple Line of Twentieth Century Business. These 
three basic principles are the focus of the company's attention in carrying out CSR in order to produce optimal output and usefulness (Elkington, 2004; Sherman, 2012).

The first basic principle of CSR is profit. Profit is the most important element and is the main goal of every company activity. Profit can be increased through increased productivity and cost efficiency, so that the company has a competitive advantage that can provide maximum value as much as possible (Sherman, 2012). In addition, the company should be responsible to pay attention to what factors are mempengeruhi productivity of the company, and must be capable of social welfare and all its stakeholders. Types of activities: Generosity is carried out sincerely to build community and human resources. Examples of activities such as tuition assistance, assistance to the health sector (Elkington, 1998).

The second is people. People who are important stakeholders in the company, so the company needs to be committed to striving to provide maximum benefits to the people (people). The company must not only have benefits for the organization but must provide economic progress to its stakeholders. The type of activity: the company's actions to go directly into the community to strengthen economic resilience. Examples: fostering SMEs, assisting credit capital, empowering local workers (Elkington, 2004).

The third is planet or environment which is something that is related to all fields of ecology and ecosystems that are bound to the company (Susanto, 2007). The company must be able to use natural resources with great responsibility and maintain environmental conditions and reduce the amount of production waste. Types of activities: implementation of a clean, safe and responsible production process. Examples: waste management, tree planting, environmental campaigns (Elkington, 1998).

CSR is a form of corporate concern based on three basic principles (3P) as described above. Briefly, the principle of the triple bottom line (3P) can be tabulated as follows:

Table 1 - Prinsip Triple Bottom Line

\begin{tabular}{lll}
\hline No CSR concept & Measurement indicator \\
\hline 1. Profit (Advantage) & $\begin{array}{l}\text { Profit becomes a business goal } \\
\text { Profit as a driver to work more efficiently } \\
\text { Profit is achieved with a standard measure of comparison with other } \\
\text { businesses } \\
\text { Profit as a tax object }\end{array}$ \\
& $\begin{array}{l}\text { Care for the welfare of the community } \\
\text { The company is aware of living in the midst of society } \\
\text { The company must be close to the community } \\
\text { T. People (Society) }\end{array}$ & $\begin{array}{l}\text { The community is the source of company life } \\
\text { The company cares about the environment }\end{array}$ \\
& $\begin{array}{l}\text { The company cares about biodiversity conservation } \\
\text { The company awares of natural resource needs } \\
\text { The company awares that it will not damage nature }\end{array}$ \\
\hline
\end{tabular}

Source: Buchari Alma (2009).

\section{METHODS OF RESEARCH}

The unit of analysis in this research is PT. Tirta Investama which is the Aqua Group branch of Cianjur. The data collection technique used is through the technique of in-depth interviews with relevant informants and key informants to answer research questions. This research uses descriptive qualitative analysis method. The purpose of qualitative analysis is to get the meaning of the relationship of variables so that they can be used to answer the problems formulated in the research (Hair, Money, Samouel, \& Page, 2006).

The first process is the first observation to obtain the necessary data such as data relating to CSR carried out at PT. Tirta Investama includes triple buttoms. Furthermore, the data analysis process is carried out with; the first is data reduction is the process of selection, focusing, simplification and abstraction of data (coarse) in the files note regarding the implementation of CSR programs at PT. Tirta Investama Cianjur factory covers the level of profit of the company (profit), community empowerment (people), and environmental preservation (plannet). The process continues throughout the research, which is four months. 
The second presentation of data is assembling information that allows researchers to draw conclusions narrative description. After the observation and interview process was completed, the researcher then presented data on the implementation of the CSR program at PT. Tirta Investama (Aqua Group) Factory Cianjur include the level of corporate profits (profit), community empowerment (people) and environmental services (plannet) so it is easy to analyze. To maintain the validity of the data in this research, researchers used data triangulation technique, which is a technique that utilizes data validity checking something else.

The Third, or the last step in data analysis is drawing conclusions and verification related to the implementation of CSR programs at PT. Tirta Investama (Aqua Group) Cianjur Factory covers the level of company profits (profit), Community empowerment (people), and environmental preservation (plannet).

\section{RESULTS AND DISCUSSION}

PT. Tirta Investama (Aqua Group) Cianjur Factory was built in 2010 in Gekbrong District, Cianjur Regency. PT. Factory Tirta Investama began operations in mid-2011 by starting to produce drinking water in $600 \mathrm{ml}$ bottles, and 19-liter gallons. Regarding CSR activities, PT. Tirta Investama has carried out these social activities starting from the establishment of the factory in 2011. The forms of CSR activities that have been carried out according to the motives for doing CSR at that time.

After conducting deep interviews with related parties who later became informants in this study, the analysis will be carried out according to the method references in this study. The next discussion is about the benefits felt by CSR beneficiary stakeholders based on the triple bottom line, which includes the level of corporate profits (profit), Community empowerment (people) and environmental conservation (planet).

The company remains to be oriented to seek economic advantage that allows it to continue to operate and expand. Profit is the most important element and is the main goal of every business activity. As stated by Jhon Elkington (1997) that companies should not only have benefits for their organizations but must provide economic progress to their stakeholders. The types of CSR activities in profit include the company's actions to go directly into the community to strengthen economic resilience, such as fostering SMEs, assisting credit capital, empowering local workers.

PT. Tirta Investama (Aqua Group) Cianjur Factory realizes the importance of maintaining the growth of company performance so that the business that is carried out continues on an ongoing basis. One of the things that must be maintained properly is the high trust of customers, which the products and services chosen provide tangible and valuable benefits to be obtained. Therefore, PT. Tirta Investama (Aqua Group) Cianjur Factory always strives to maintain customer trust in the quality of products sold and provide the best service. PT. Tirta Investama (Aqua Group) Cianjur Factory maintains product quality through the application of an ISO 9001: 2008 international standardized quality management system that is consistently applied. PT. Tirta Investama (Aqua Group) Cianjur Factory always opens opportunities for independent surveyors to carry out periodic checks on commitments in the implementation of production systems and the consistency of product quality quality according to the required standards.

In addition to maintaining products and resolving every customer complaint that comes in, PT. Tirta Investama (Aqua Group) Cianjur factory seeks to maintain the product image and guarantee the availability of products on the market, through the implementation of various forms of marketing communication. The purpose is to strengthen the position of products and brands in the market and maintain customer loyalty (Diugwu, 2011). PT. Tirta Investama (Aqua Group) Cianjur Factory has allocated a portion of its profits to CSR costs, where the amount of the cost has always increased, which amounted to 2.3 billion in 2016 and increased to 4.2 billion in 2017.

The profit itself is essentially an additional income that can be used to guarantee the survival of the company. While the activities that can be taken to boost profits include 
increasing productivity and making cost efficiency, so that the company has a competitive advantage that can provide added value as much as possible. The link between profit and CSR is when a company makes a profit, it is not solely because the company is there, but there are other parties who help, namely stakeholders. Therefore the company should share the profits with its stakeholders in various forms. This is where the essence of profit in the triple bottom line, because above the profits obtained by the company there are rights of other parties who are entitled also for the profits.

The company must have concern for human welfare. Some CSR programs are often developed by companies such as: scholarships for students in the environment surrounding the company, the establishment of education and health facilities, strengthening local economic capacities and so forth. Elkington (1997) reveals that a business must be responsible for advancing and social welfare and all its stakeholders. Some types of CSR activities in people include generosity done sincerely to build society and human resources, such as education, health costs.

The order of society is not spared from the view of CSR, through its assistance formed the Village Community Development Institution (LPMK), as the institution that manages the program and is responsible for programs in the village. With the existence of LPMK, the community is supported in managing the program, especially the ability to manage the organization. The initial stage after the opening LPMK in Cianjur, has also made the introduction of entrepreneurship and manufacture AD / ART. It's very useful for the people who in their lives also need to organize.

The village head of Gekbrong said that PT. Tirta Investama (Aqua Group) Cianjur Factory provides clean water assistance to residents of Gekbrong Village and Babakan Village and also toilets in Majlis Taklim, Kampung Babakan. Hopefully the community can take care of it and hopefully the company is still willing to help in other areas.

The village head of Kebon Peteuy said that PT. Tirta Investama has provided SAB and toilets in the Darul Anwar Islamic Boarding School who was in our village postscript as institutions that educate the younger generation, but has lacked the facilities at this time has been completed and is already in use may be useful and blessings. Hopefully next year the company will still provide assistance to our citizens who are still experiencing shortages of clean water.

The village head Songgom said PT. Tirta Investama (Aqua Group) Cianjur Factory has facilitated residents to access clean water in Pancuran Luhur village through connecting clean water from PAM Bumdes, hopefully in the future cooperation can be improved in handling the difficulties of community clean water together with the bumdes water company managed by $\mathrm{CV}$. Barokah. Currently there are 25 houses installed and can be utilized, hopefully with clean water facilities this can improve the quality of public health.

The following are some of the community empowerment activities that have been carried out by PT. Tirta Investama (Aqua Group) Pabrik Cianjur namely:

Integrated Farming System (IFS) Program. Agriculture has become a local context as well as the local wisdom of the people in Gekbrong Village which is also the location of the establishment of the Cianjur AQUA factory. The AQUA Cianjur factory is in an area surrounded by community agricultural fields both rice farming and horticultural agriculture. It's just that most of the agricultural fields are managed by the community around the plant in an environmentally unfriendly manner. One of them still uses chemical pesticides as the foundation of farmers in caring for their agricultural crops from pest attacks.

The use of chemical pesticides is certainly very dangerous not only for the health of farmers, but will also bring a negative domino effect to the environment, including a threat to Aqua water sources. The threat of contamination of Aqua water sources from pesticides and chemical fertilizers can have a fatal impact on the sustainability of Aqua's business. IFS program based on environment-friendly agriculture is expected to have an impact on improvement of economic and social aspects as well as environmental preservation. Increased economic aspects are derived from the existence of added value of environmentally friendly agricultural products, where consumers are aware of products from Eco-friendly agricultural products willing to provide more prices. 
Healthy and Organic Rice Agriculture. The IFS Program activities have led to the birth of the Cianjur Organic Farmers Association in 2011 as a local institution that guides farmers in the practice and development of environmentally friendly agriculture. This year's IFS will continue to strengthen the achievements of the previous program with a focus on revitalizing Hipoci agricultural land. The IFS program will ensure that the implementation of environmentally friendly agricultural practices can be achieved sustainably from the aspect of production to post-harvest and is integrated with the HIPOCI business unit, the HIPOCI Bisnis Center.

Collaboration with Hipoci Business Center. IFS collaboration with the Hipoci Business Center works well. HIPOCI go organic rice supply for HBC is part of the collaboration of upstream downstream activities. Hipoci focused on preparing go organic rice products while HBC was tasked with marketing Hipoci rice products under the Orisa brand. Hipoci has absorbed wet grain from members for the period October 2017. November 2017 reached $4,022 \mathrm{~kg}, 2,261 \mathrm{Kg}$ in the period October 2017 and 1,716 $\mathrm{Kg}$ for the period of November 2017. Hipoci then carried out postharvest activities ranging from drying, grinding, and sorting to packaging. The rice products are then sold to the AHS Distributor with the name Orisa rice product. The total Purchase Order (PO) of Orisa rice to $\mathrm{HIPOCI}$ in the last 2 months reached $7,050 \mathrm{~kg}$. The real contribution of CSR AQUA for the community is carried out through several programs. CSR AQUA contributes to public health through the Water Access, Sanitation and Hygiene (WASH) program. By running the WASH program, AQUA believes that every individual has the right to access clean water to form a healthy generation so that they have a better national competitiveness.

Company concerned about the environment and sustainability of biodiversity. Jhon Elkington (1997) cited by Hasibuan and Sedyono (2006: 73) states that companies must be able to use natural resources very responsibly and maintain environmental conditions and minimize the amount of production waste. The types of activities include the application of clean, safe and responsible production processes, such as waste management, tree planting, environmental campaigns. Some CSR programs that are based on this principle are usually in the form of greening the environment, providing clean water facilities, improving settlements, developing tourism (ecotourism) and so on. The following are some of the environmental conservation (planet) activities that have been carried out by PT. Tirta Investama (Aqua Group) Pabrik Cianjur namely:

Taman Kehati. Taman Kehati program is one of the conservation programs carried out in the park area of the AQUA Cianjur factory. Kehati Park is a reserve area of local biological natural resources outside the forest area that has in situ and / or ex situ conservation functions, especially for plants that pollinate and / or seed dispersion must be assisted by animals with the structure and composition of their vegetation to support the sustainability of pollinating animals and seed dispersers (Permen LH No.3 tahun 2012).

The purpose of the Kehati Park program is to save various species of native / local plants that have a very high level of threat to their sustainability and with the vegetation structure supporting the sustainability of various species of animals whose lives depend and influence the vegetation.

PT. Tirta Investama (Aqua Group) Cianjur Factory has designed the Taman Kehati program for a period of 5 years (2016 to 2020). The first phase was carried out in 2016. In 2017 the Kehati Cianjur Park project began in May and this is the second year as the Road Map has been prepared in the grand design book. In 2017 Aqua Cianjur conducted the Taman Kehati program continuing the program the previous year with the main activity of planting fruit trees and endemic species in the Kehati Park Cianjur Zone II Plant as many as 220 trees.

Conservation Program Towards Sustainable Cianjur. Forest and land conservation are basically based on the importance of forests and land as a place to live biodiversity in them, as well as regulating water systems and soil fertility that have high value for human life. The purpose of the conservation program towards Cianjur Lestari is an effort to rehabilitate forests and land by planting trees in the conservation area of Taman Nasional Gunung Gede 
Pangrango (TNGGP) and Citarum-Cibeleng watershed / Sub-watershed area in Tabrik Village, Gekbrong Village.

Conservation Taman Nasional Gunung Gede Pangrango (TNGGP). Conservation Program TNGGP 2017 as an integral part of the project Partnership Agreements between the Directorate General of Forest Protection and Nature Conservation (DG PHKA) and Directorate-General of Watershed Management and Forest Protection (DG BPDASHL) in 2014 until 2019 through the Biodiversity Conservation-based Community Empowerment Around Conservation Areas. Program Achievements the implementation of the program began with the formation of a conservation group as the main subject for the implementation of the program called the Hejo Cipruk Forest Farmer Group (KTH) consisting of 25 farmers. This is in line with the principle of a community empowerment based program. The implementation of tree planting is the main activity of this conservation program that has been carried out in the Cadas Hanging block and Bedeng block, precisely in the village of Tabrik, Gekbrong Village, Gekbrong District with 3,500 trees.

Cibeleng Sub-watershed Conservation. As a form of company concern for environmental improvement and supporting the save global warming campaign, PT Tirta Investama Cianjur (Aqua Cianjur) implements various environmental improvement programs, especially in the upstream and middle section, one of which is through the Cibeleng Subwatershed Conservation Program in 2017. Expected the existence of this program can answer various problems faced by Cibeleng Sub-watershed, including pollution of waste, pollution of chemical pesticides, the conversion of riverbanks and lack of perennials around the river. These problems if they don't get immediate treatment can be a threat to the sustainability of the Cibeleng River in the future. Through this program, involving the community is expected to reduce Cibeleng sub-watershed problems.

Water Access, Sanitation and Hygiene (WASH) Program. As a form of commitment to the community and also to support the government's program target to achieve $100 \%$ Universal Access by 2020, AQUA contributes to improving access to clean water for the community by running a Water Access, Sanitation and Hygiene (WASH) program / Access to Clean Water and Environmental Health. . By running the WASH program, AQUA believes that every individual has the right to access clean water to form a healthy generation so that they have a better national competitiveness. Commitment to contribute to the achievement of the Universal Access is also in line with the double commitment of Danone (dual commitment) is to ensure the sustainability of the business and contribute to social and environmental progress.

WASH program run by AQUA Factory Cianjur based on results of social and environmental mapping, and analysis of community needs related to the level of access to clean water and sanitation, especially in Cianjur area. Program planning is carried out in a participatory manner by involving the community and other stakeholders, to foster ownership so that they can play more roles and have responsibility in managing and maintaining clean water installation systems, starting from machinery, electricity and piping systems so that benefits can continue felt on an ongoing basis. The program began in 2013 until 2017 and has provided more than 120 points of location for clean water facilities (SAB).

Development of Clean Water Facilities. One of the problems faced by the community water supply is low access to clean water supply. There are several areas around Cianjur's AQUA factory which still have to walk far to access clean water sources because the wells they have experience drought, especially during the dry season. The low access to clean water from the community has been well responded by AQUA Cianjur through the implementation of CSR programs in the form of the WASH program.

Community Based Total Sanitation. Community-based Total Sanitation, hereinafter referred to as CBTS, is an approach to change the behavior of hygiene and sanitation through community empowerment using the triggering method. CBTS activities are an important part that cannot be separated from the WASH program. CBTS activities are synergized with the work program of the Health Office and Gekbrong Health Center as implementing partners to build awareness of the importance of clean living, sanitation and environmental health in the society. 
The CBTS activities began with the formation of health cadres from representatives of each of the established SABs who came from Gekbrong Village, Kebonpeuteuy Village and Songgom Village and with a total of 14 people. The role of health workers is very important as well as the driving spearhead CBTS activities in the community to continuously undone CBTS promotion and sustainable. Seeing so much the role of health workers as an arm CBTS in society, the health cadres is also equipped with a variety of capacity building activities. Among them are training for Trainer (TOT) training for health cadres with facilitators from the Gekbrong District Health Center.

\section{CONCLUSION}

The application of CSR relates to the level of profit of the company of PT. Tirta Investama (Aqua Group) Cianjur Factory contributes to the economic activities of the local community through the Integrated Farming System (IFS) Program. IFS program based on environment-friendly agriculture is expected to have an impact on improvement of economic and social aspects as well as environmental preservation. Increased economic aspects are derived from the existence of added value of environmentally friendly agricultural products, where consumers are aware of products from Eco-friendly agricultural products willing to provide more prices.

The implementation of CSR related to community empowerment (people) is actually implemented by PT. Tirta Investama (Aqua Group) Cianjur Factory in the form of Integrated Farming System (IFS) Program, Healthy and Organic Rice Agriculture, and Collaboration with Hipoci Business Center. The implementation of CSR is related to environmental preservation (plannet) of PT. Tirta Investama (Aqua Group) Cianjur Factory can be seen from environmental CSR programs that are actually carried out to save and preserve the environment.

From the CSR activities of PT. Tirta Investama is based on the form of activities carried out with the triple bottom line approach, there is still public awareness of business sustainability. Preferably the companies make their CSR program orientation, where such programs are not only aimed at building social facilities, providing assistance or physical infrastructure for communities around the area of the company, but rather aimed at broader community education on CSR issues and their impact. This is needed to increase public awareness about the importance of the results that can be achieved through CSR programs of this kind, so that public awareness will be formed.

\section{REFERENCES}

1. Bocken, N. M. P., Short, S. W., Rana, P., \& Evans, S. (2014). A literature and practice review to develop sustainable business model archetypes. Journal of Cleaner Production. https://doi.org/10.1016/j.jclepro.2013.11.039

2. Buhmann, K. (2006). Corporate social responsibility: What role for law? Some aspects of law and CSR. Corporate Governance. https://doi.org/10.1108/14720700610655187

3. Carter, C. R., \& Easton, P. L. (2011). Sustainable supply chain management: Evolution and future directions. International Journal of Physical Distribution and Logistics Management. https://doi.org/10.1108/09600031111101420

4. Davis, G. F. (2005). Social movements and organization theory. Cambridge studies in contentious politics.

5. Detre, J. D., \& Gunderson, M. A. (2011). The triple bottom line: What is the impact on the returns to agribusiness? International Food and Agribusiness Management Review.

6. Diugwu, I. (2011). Knowledge Acquisition and Sharing: A Sustainable Source of Competitive Advantage in Supply Chains. Proceedings of the International Conference on Intellectual Capital, Knowledge Management \& Organizational Learning, (1970), 157163.

7. Elkington, J. (1998). Partnerships from cannibals with forks: The triple bottom line of 21stcentury business. Environmental Quality Management. 
https://doi.org/10.1002/tqem.3310080106

8. Elkington, J. (2004). The triple bottom line: Does it all add up. The triple bottom line: Does it all add up. https://doi.org/10.1021/nl034968f

9. Freeman, I., \& Hasnaoui, A. (2011). The Meaning of Corporate Social Responsibility: The Vision of Four Nations. Journal of Business Ethics. https://doi.org/10.1007/s10551-0100688-6

10. Guillén, M., \& Mele, D. (2006). Intellectual Evolution of Strategic Management and its Relationship With Ethics and Social Responsibility. IESE Business School Working Paper, 3(658). https://doi.org/10.2139/ssrn.960663

11. Hair, Money, Samouel, \& Page. (2006). Research Methods for Business. Education and Training. https://doi.org/http://dx.doi.org/10.1108/et.2007.49.4.336.2

12. Hambrick, D. C. (1981). Environment, strategy, and power within top management teams. Administrative Science Quarterly, 26(2), 253-275. https://doi.org/10.2307/2392472

13. Hidayati, N. D. (2011). Pattern of corporate social responsibility programs: A case study. Social Responsibility Journal. https://doi.org/10.1108/17471111111114576

14. Kleine, A., \& von Hauff, M. (2009). Sustainability-driven implementation of corporate social responsibility: Application of the integrative sustainability triangle. Journal of Business Ethics. https://doi.org/10.1007/s10551-009-0212-z

15. Lu, W., Chau, K. W., Wang, H., \& Pan, W. (2014). A decade's debate on the nexus between corporate social and corporate financial performance: A critical review of empirical studies 2002-2011. Journal of Cleaner Production, 79, 195-206. https://doi.org/10.1016/j.jclepro.2014.04.072

16. Luu, T. T. (2017). CSR and organizational citizenship behavior for the environment in hotel industry: The moderating roles of corporate entrepreneurship and employee attachment style. International Journal of Contemporary Hospitality Management, 29(11), 2867-2900. https://doi.org/10.1108/IJCHM-02-2016-0080

17. Norman, W., \& MacDonald, C. (2012). Getting to the Bottom of "Triple Bottom Line." Business Ethics Quarterly. https://doi.org/10.5840/beq200414211

18. Painter-Morland, M. (2006). Triple Bottom-Line Reporting as Social Grammar: Integrating Corporate Social Responsibility and Corporate Codes of Conduct. SSRN. https://doi.org/10.1111/j.1467-8608.2006.00457.x

19. Responsibility, C. S., \& Dixon, T. (2014). Corporate Social Responsibility, the Triple Bottom Line, Standardization and Brand Management in Houston, Texas. Social Responsibility.

20. Sherman, W. R. (2012). The triple bottom line: The reporting of "Doing Well" \& "Doing Good." Journal of Applied Business Research. https://doi.org/10.19030/jabr.v28i4.7051

21. Tate, W. L., Ellram, L. M., \& Kirchoff, J. F. (2010). Corporate social responsibility reports: A thematic analysis related to supply chain management. Journal of Supply Chain Management. https://doi.org/10.1111/j.1745-493X.2009.03184.x

22. VALOR, C. (2005). Corporate Social Responsibility and Corporate Citizenship: Towards Corporate Accountability. Business and Society Review. https://doi.org/10.1111/j.00453609.2005.00011.x

23. Żak, A. (2015). Triple bottom line concept in theory and practice. Prace Naukowe Uniwersytetu Ekonomicznego We Wrocławiu. https://doi.org/10.15611/pn.2015.387.21 